\title{
Tolerance to salinities shocks of the invasive mussel Limnoperma fortunei under experimental conditions
}

\author{
Luciana G. Angonesi, Natália G. da Rosa \& Carlos E. Bemvenuti
}

Laboratório de Ecologia de Invertebrados Bentônicos, Departamento de Oceanografia (FURG). PO Box 474, $96201-900$ Rio Grande, RS, Brazil. (luangonesi@hotmail.com)

\begin{abstract}
The golden mussel, Limnoperna fortunei (Dunker, 1857), has been found in the estuarine regions of South America, including the Patos Lagoon (Brazil), a huge choked lagoon with an estuarine region that is highly unstable chemically. Limnoperna fortunei space-temporal variability in the lagoon's estuarine region demonstrated the need to evaluate this species' ability to survive under salinity shocks. A set of experiments was conducted under controlled laboratory conditions. Specimens were tested under salinities of 2, 4, 6, 8 and 12 ppt, and were exposed for periods of 24, 48, 72, 96 and 240 hours. The mussel can survive (90\%) up to a salinity shock of $2 \mathrm{ppt}$ for periods of at least 10 days. Considering the influence of climatic and stochastic events and the chemical instability of the Patos Lagoon estuarine region, it's unlikely that populations could survive for longer periods (more than a year) in this area.
\end{abstract}

KEYWORDS. Limnoperna fortunei, golden mussel, salinity shocks, physiological tolerance, invasion.

RESUMO. Tolerância do bivalve invasor Limnoperna fortunei a choques de salinidade sob condições experimentais. O mexilhão-dourado Limnoperna fortunei (Dunker, 1857), tem sido encontrado nas regiões estuarinas da América do Sul, incluindo a Laguna dos Patos (Brasil), uma enorme laguna de choque com uma região estuarina altamente instável quimicamente. A variabilidade espaçotemporal de L. fortunei na região estuarina desta laguna evidenciou a necessidade da avaliação da sobrevivência desta espécie sob choques de salinidade. Experimentos foram conduzidos em condições controladas de laboratório. Os exemplares foram submetidos a choques de salinidade de 2, 4, 6, 8 e 12 ppt, por períodos de 24, 48, 72, 96 e 240 horas. O mexilhão pode sobreviver (90\%) por períodos de no mínimo 10 dias após um choque de salinidade 2. Considerando a influência de eventos climáticos e estocásticos e a instabilidade química da região estuarina da Laguna dos Patos, é improvável que populações possam sobreviver por períodos maiores (mais de um ano) neste ambiente.

PALAVRAS-CHAVE. Limnoperna fortunei, mexilhão-dourado, choque de salinidade, tolerância fisiológica, invasão.

The Patos Lagoon is a huge choked lagoon $(10,300$ $\mathrm{km}^{2}$ ) with a long narrow entrance channel (750 $\mathrm{m}$ width). The estuarine region (sensu CLoss, 1965) is restricted to the southern portion of the lagoon and comprises 10\% of its total area. The estuarine region has a highly variable salinity, which makes it a chemically unstable area (NIENCHESKI \& BAUMGARTEN, 1997). This lagoon has been invaded by the golden mussel Limnoperna fortunei (Dunker, 1857) since the end of the 1990s (MANsur et al., 1999, 2003).

Limnoperna fortunei (Mytilidae) is the only freshwater member of its family (MONTALTO \& DRAGO, 2003) and it is indigenous to Southeast Asia, where it's found in rivers, streams (MORTON, 1977) and near the mouths of estuaries (HwANG et al., 1981). It was first discovered in South America (La Plata river, Argentina) in 1991, when argentinian imports from Hong Kong and Korea had increased (DARRIGRAN \& PASTORINO, 1995). The species probably entered the Argentine territory as larvae or young adults, carried in the ballast water of transoceanic freighters (DARRIGRAN \& PASTORINO, 1995).

This species is apparently adapting to different environments along its invasion routes; between 1991 and 1999 invaded four countries: Argentina, Uruguay, Paraguay and Brazil. It traveled at a speed of about 240 $\mathrm{km}$ per year(DARRIGRAN \& DRAGO, 2000). Throughout its distribution range, $L$. fortunei has inhabited a wide variety of environments, from strictly fresh water to brackish waters in the La Plata river and Patos Lagoon estuaries (Darrigran, 2002; Capítoli \& BemVenuti, 2005).
At the end of 1998 and the beginning of 1999, the golden mussel was registered for the first time in the Guaiba Lake Basin, Patos Lagoon's northernmost region. After two years it had colonized the lagoon's limnic and pre-limnic region (MANsur et al., 1999, 2003). The first appearance of the Limnoperna in northern estuarine region was in 2002, in the São Gonçalo channel. However, through the size of the specimens, the estimate of the period of the cohorts' establishment indicated that these individuals would have originated from cohorts in the spring of 2001 (CAPítoli \& BeMveNuti, 2004).

Limnoperna fortunei was recorded in the Patos Lagoon's southern estuarine region, near the entrance channel, in 2003, after a long period of freshwater preponderance, due to the meteorological event El Niño, which increased the pluviosity in the Patos Lagoon basin. In the following year, after an intense estuarine salinization, the mussel was no longer found in Patos Lagoon's southernmost estuarine region. However, this species keeps persistent population stocks inside the Pelotas Stream and in the pre-limnic and limnic regions of the lagoon (CAPítoli \& Bemvenuti, 2004, 2005).

Being Patos Lagoon a choked lagoon, where the salinity of the estuarine region can vary up to twenty units in a one-hour period (CRUz et al., 1982), and considering $L$. fortunei's space-temporal variability in the lagoon's estuarine region, this study aims to evaluate the species' ability to survive under salinity shocks. 


\section{MATERIAL AND METHODS}

In order to evaluate the tolerance of $L$. fortunei at different salinity levels, a set of experiments was conducted in a laboratory under controlled conditions. The specimens were collected in June 2005 from a Patos Lagoon bay called Lagoa Pequena (Fig. 1), located between the cities of Pelotas and Turuçu. The specimens, attached to wooden logs, were placed in aerated tanks containing freshwater from the Santa Bárbara Barrage (Fig. 1) for approximately fifteen days before the experiments began. Pumping water through the barrage provided a constant source of food.

The specimens used in the tests had size ranges between fifteen and twenty millimeters, and were carefully separated by cutting their byssus with a scissors. For each treatment, forty specimens were equally spaced in four aerated aquariums (four replicates), and, in the same way, forty other mussels were placed in four aerated aquariums as controls. Water was not renewed during the tests, limiting the specimens' food during the experiment.

Mussels were kept in fresh water under controlled conditions, while the L. fortunei specimens under salinity treatments were transferred from fresh water directly to the saline solution to be tested. The mussels were submitted to salinity shocks of 2, 4, 6, 8 and 12 ppt during periods of exposure of 24, 48, 72, 96 and 240 hours. Water temperature, dissolved oxygen, oxygen saturation (YSI 55), $\mathrm{pH}$ (PHTEK pH100), conductivity (Corning CD55), $\mathrm{CO}_{2}$ and alkalinity (titulation) were registered at the initial and final periods in each test. The mussels that survived were never used in subsequent experiments. Specimens were considered alive when they closed their valves in response to a stimulus or when valve-closed mussels resisted forcible valve opening. The dead mussels always showed these valves open. A Mann-Whitney U Test was applied to analyze the differences in the survival time between treatments and respective controls. A significance level of $\mathrm{p}<0.05$ was used in the statistical test.

\section{RESULTS}

During the tests, water temperature varied from 15 to $22{ }^{\circ} \mathrm{C}$, and the oxygen saturation was always above $75 \%$. Pronounced variations in the other variables between treatments and controls were not observed.

The relationship between salinity and exposure time was evident, which coincided with the number of

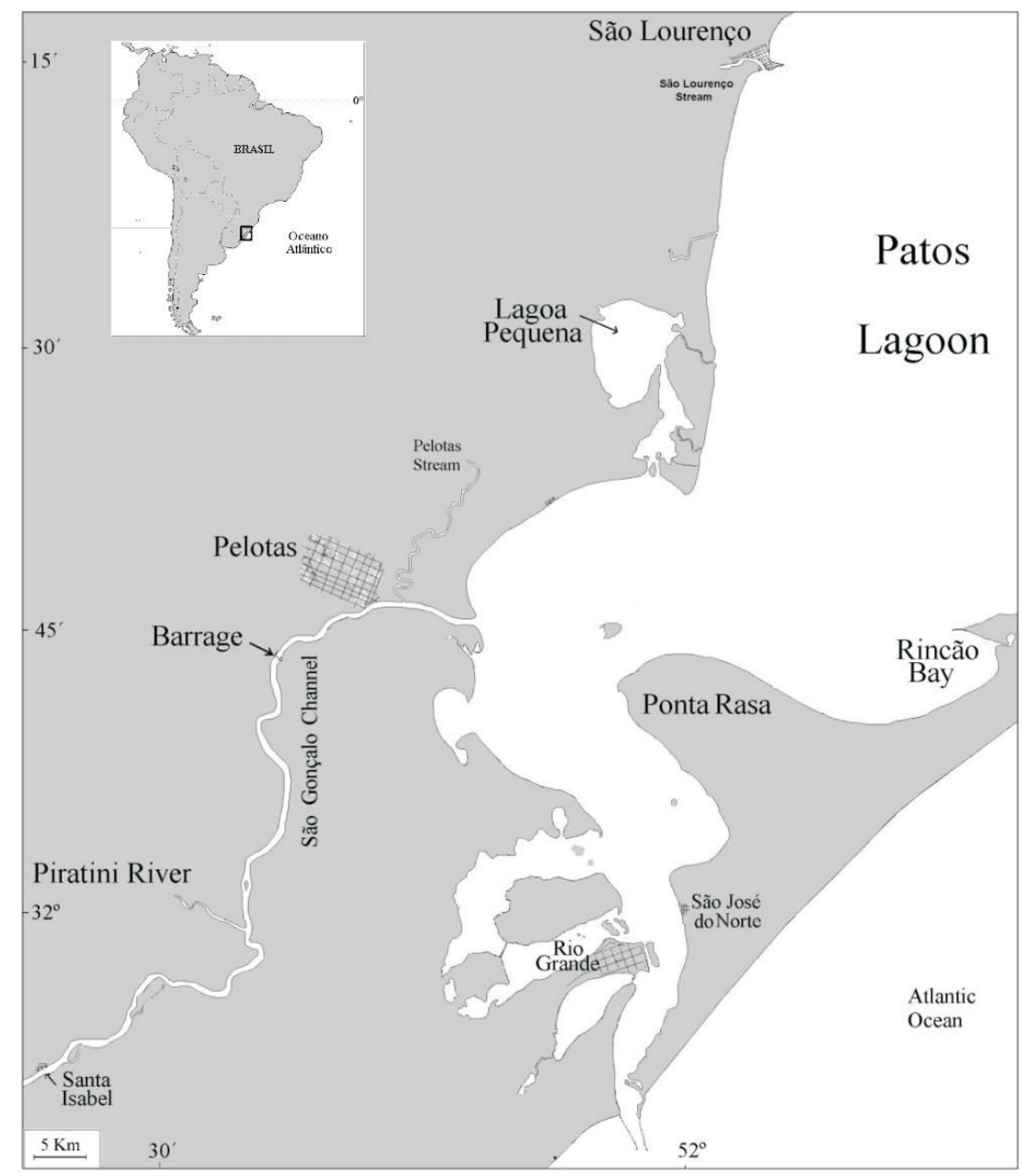

Fig. 1. Patos Lagoon southern region showing Lagoa Pequena bay where the specimens of Limnoperna fortunei and water to the experiment were collected. 
survivors in the treatments. Less L. fortunei survivors were registered in the treatments combining high salinity and long exposure times (Tab. I). It was observed a high significant mortality of $L$. fortune $i$, in all treatments, after 240 hours of experiment (Tab. II).

Survival rates were greater than or equal to $85 \%$ for mussels under salinities of 2, 4, and $6 \mathrm{ppt}$ in periods up to 96 hours. In the 240-hour period, the mussels' survival rates were seriously affected in salinities of 4 and 6 ppt, with more than $20 \%$ of the individuals not surviving (Fig. 2 ). In the 8 and $12 \mathrm{ppt}$ salinity tests, L. fortunei survival was affected in the first 24 hours, when the number of live animals declined gradually. After 240 hours in 6,8 and 12 ppt salinity levels, no live specimen was registered. Control treatments invariably showed $100 \%$ survival (salinity 0 , for all time periods).

Table I. Mean survival (\%) of Limnoperna fortunei (Dunker, 1857) at different salinity levels and periods of exposure (Salinity 0 , control; SD, standard deviation).

\begin{tabular}{cccccccccccc}
\hline Timel & \multirow{2}{*}{$\begin{array}{c}\text { Hours } \\
\text { Salinity }\end{array}$} & Mean & SD & Mean & SD & Mean & SD & Mean & SD & Mean & SD \\
\hline 0 & 100 & 0 & 100 & 0 & 100 & 0 & 100 & 0 & 100 & 0 \\
2 & 100 & 0 & 100 & 0 & 100 & 0 & 100 & 0 & 90 & 0 \\
4 & 100 & 0 & 100 & 0 & 100 & 0 & 95 & 5,7 & 20 & 8,1 \\
6 & 100 & 0 & 100 & 0 & 95 & 5,7 & 85 & 13 & 0 & 0 \\
8 & 97,5 & 5 & 92,5 & 5 & 65 & 5,7 & 57,5 & 5 & 0 & 0 \\
12 & 97,5 & 5 & 87,5 & 5 & 55 & 10 & 25 & 5,7 & 0 & 0 \\
\hline
\end{tabular}

Table II. Significance level of Limnoperna fortunei (Dunker, 1857) survival (Mann-Whitney U Test) in salinity (S) treatments in relation to $100 \%$ survival of the control (Zero Salinity).

\begin{tabular}{llllll}
\hline Time & $\mathrm{S}-2 \mathrm{ppt}$ & $\mathrm{S}-4 \mathrm{ppt}$ & $\mathrm{S}-6 \mathrm{ppt}$ & $\mathrm{S}-8 \mathrm{ppt}$ & $\mathrm{S}-12 \mathrm{ppt}$ \\
\hline $24 \mathrm{~h}$ & $\mathrm{p}>0.05$ & $\mathrm{p}>0.05$ & $\mathrm{p}>0.05$ & $\mathrm{p}>0.05$ & $\mathrm{p}>0.05$ \\
$48 \mathrm{~h}$ & $\mathrm{p}>0.05$ & $\mathrm{p}>0.05$ & $\mathrm{p}>0.05$ & $\mathrm{p}=0.04$ & $\mathrm{p}=0,02$ \\
$72 \mathrm{~h}$ & $\mathrm{p}>0.05$ & $\mathrm{p}>0.05$ & $\mathrm{p}>0.05$ & $\mathrm{p}=0,02$ & $\mathrm{p}=0,02$ \\
$96 \mathrm{~h}$ & $\mathrm{p}>0.05$ & $\mathrm{p}>0.05$ & $\mathrm{p}=0,047$ & $\mathrm{p}=0,02$ & $\mathrm{p}=0,02$ \\
$240 \mathrm{~h}$ & $\mathrm{p}=0,008$ & $\mathrm{p}=0,02$ & $\mathrm{p}=0,008$ & $\mathrm{p}=0,008$ & $\mathrm{p}=0,008$ \\
\hline
\end{tabular}

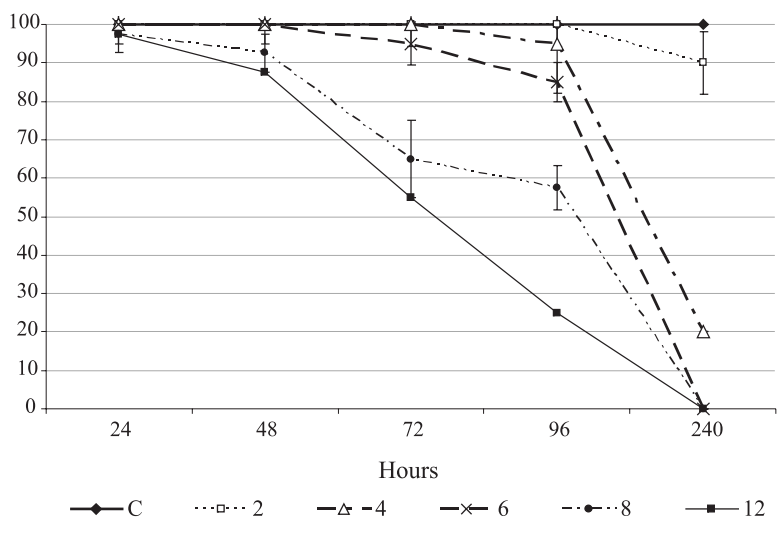

Fig. 2. Survival (\%) of Limnoperna fortunei (Dunker, 1857) in laboratory experiments under salinities treatments $2,4,6,8$, and $12 \mathrm{ppt}$ in the experiment control ( $\mathrm{C}$, zero salinity).

\section{DISCUSSION}

Ninety percent of the individuals of Limnoperna fortunei survived for at least 10 days after a salinity shock of 2 ppt. While in salinity shocks of 4 and 6 this species showed high tolerance only in the first 96 and 72 hours, respectively. After this period the species survival was greatly affected .

This tolerance can be found in L. fortunei in the Asian and South American estuarine regions, as in the Changjiang River (China) (Hwang et al., 1981), La Plata river (Argentina) (DARRIGRAN, 2002), and in the Patos Lagoon southern region (Brazil) (CAPÍTOLI \& BEMVENUTI, 2004, 2005).

In the present study, L. fortunei survival differs from the findings in DEATON et al. (1989), where $80 \%$ of the animals survived in a salinity of $6.8 \mathrm{ppt}(200 \mathrm{mOsm})$ for time periods of three weeks or more, and less than a week in a salinity of $13.6 \mathrm{ppt}(400 \mathrm{mOsm})$. In our study, $L$. fortunei specimens could only tolerate a salinity of $2 \mathrm{ppt}$ for a period of up to ten days. For this same time period, salinities starting at $4 \mathrm{ppt}$ were fatal for at least $80 \%$ of the organisms. The golden-mussel's higher tolerance, found by DEATON et al. (1989) through salinity and osmotic regulation experiments (hemolymph osmotic and ionic composition and tissue amino acid content) may be related to the species' ecological adaptation from Asia, the species' natural habitat.

Our results concerning L. fortunei's salinity tolerance coincided with what was observed in the golden mussel distribution in the La Plata river estuary, where colonies were registered in areas where the mean salinity does not exceed 3 ppt (DARRIGRAN \& PASTORINO, 1995; DARRigran, 2002; Brugnoli et al., 2005).

An invasive species should have several characteristics to be successful in the new environment: a short lifespan (two to three years), rapid growth, high fecundity, the ability to colonize a wide range of habitats, a wide range of physiological tolerances, wide genetic variability, phylogenetic plasticity, among others (MORTON, 1996). Limnoperna fortunei has been reported under a variety of synonyms, including subspecies (RICCIARDI, 1998). This plethora of species' synonyms reflects the high phenotypical variation that allows Limnoperna to thrive in a broad range of aquatic environments (RICCIARDI, 1998) and probably tolerate wide salinity variations, as well as occurs in this species' expected lifespan (which can vary from one to more than four and a half years, depending on the location studied) (MAGara et al., 2001).

According to the present study, the $L$. fortunei populations in the Patos Lagoon probably do not tolerate salinities above 2 or 3 ppt, but in salinities lesser than or equal to this value, it's likely that the populations will persist for an indefinite time and retain feeding, growth and reproductive abilities. At salinities around $4 \mathrm{ppt}$, the organisms could survive for a few days without, however, tolerating the harsh environmetal conditions, and as a result, it would become extinct.

In agreement, CAPítoli \& Bemvenuti $(2004,2005)$ registered $L$. fortunei colonies in the estuarine region of Patos Lagoon during the high precipitation levels due to 
the 2002/2003 El Niño (between August 2002 and February 2003), which caused a prevalence of low salinities in the estuarine region. Between the summer of 2004 and the autumn of 2005, the most severe dryness in the last forty years in the state of Rio Grande do Sul was registered, resulting in a high salinity period in the Patos Lagoon estuarine region. The surface salinity records oscillated between 10 and 30 ppt in the southern region and between 5 and 17 ppt in the northern region of the estuarine area, causing the mortality of the golden mussel populations (CAPÍTOLI \& BEMVENUTi, 2005). The species wasn't registered in the estuarine region of the Patos Lagoon in the last census of L. fortunei (CAPítoli \& Bemvenuti, 2005; Bemvenuti, march 2006 - pers. obs.).

Considering the influence of climatic and esthocastic events and the chemical instability of the Patos Lagoon estuarine region (NIENCHESKI \& Baumgarten, 1997), it's unlikely that L. fortunei populations will survive for long periods (more than a year) in this area. However, due to L. fortnunei opportunistic lifestyle, cannot be discarded that in the future, this specie might increase its tolerance to the salinity limits in the South American estuaries, which reinforces the need for studies on its physiological tolerance.

Acknowledgments. We are grateful to Oceanographer Sergio Piedras (Universidade Católica de Pelotas - UCPEL), Nilton Jair da Silva and M.Sc. Michel S. Gandra, for their helpful assistance.

\section{REFERENCES}

Brugnoli, E.; Clemente, J.; Boccardi, L.; Borthagaray, A. \& Scarabino, F. 2005. Golden mussel Limnoperna fortunei (Bivalvia: Mytilidae) distribution in the main hydrographical basins of Uruguay: update and predictions. Anais da Academia Brasileira de Ciências 77(2):235-244.

CApítoli, R. R. \& Bemvenuti, C. E. 2004. Distribuição do mexilhão dourado Limnoperna fortunei (Dunker, 1857) na área estuarina da Lagoa dos Patos e Canal São Gonçalo. Anais do VI Simpósio de Ecossistemas Brasileiros, Publ. ACIESP 110(1):98-107.

2005. Cenários de distribuição e processo de colonização do mexilhão dourado Limnoperna fortunei (Dunker 1857) entre as bacias da Lagoa dos Patos e Lagoa Mirim (RS-Brasil). Disponível em: <http:// www.mma.gov.br/invasoras/>. Acesso em: 15.06.2006.

Closs, D. 1965. New observations on the ecological subdivision of the Patos Lagoon southern Brazil. Boletim do Instituto de Ciências Naturais 24. Porto Alegre, UFRGS, RS. 35p.
Cruz, M. H. S.; Calliari, L. J.; Cardoso, J. N.; Hartman, C. \& KANTin, R. 1982. Flutuações horárias das características físicas e químicas na desembocadura do estuário da Lagoa dos Patos. Atlântica 5(2):32.

DARrigran, G. 2002. Potential impact of filter-feeding invaders on temperate inland freshwater environments. Biological Invasions 4:145-156.

Darrigran, G. \& Drago, I. E. 2000. Invasion of the exotic freshwater mussel Limnoperna fortunei (Dunker, 1857) (Bivalvia: Mytilidae) in South America. The Nautilus 114(2):69-73.

Darrigran, G. \& Pastorino, G. 1995. The recent introduction of a freshwater Asiatic bivalve, Limnoperna fortunei (Mytilidae) into South America. The Veliger 38(2):171-175.

Deaton, L. E.; Derby, J. S.; Duhedar, N. \& Greenberg M. J. 1989. Osmoregulation and salinity tolerances in two species of bivalve mollusc: Limnoperna fortunei and Mytilopsis leocophaeta. Journal of Experimental Marine Biology and Ecology 133:67-79.

Hwang, Z.; Li, C.; Zhang, L.; Li, F. \& Zheng, C. 1981. The distribution of fouling organisms in Changjiang river estuary. Oceanologia et Limnologia Sinica 12:531-537.

Magara, Y.; Matsui, Y.; Goto, Y. \& Yuasa, A. 2001. Invasion of the non-indigenous nuisance mussel, Limnoperna fortunei, into water supply facilities in Japan. Journal of Water Supply: Research and Technology 50(3):113-124.

Mansur, M. C. D.; Richinitti, L. M. Z. \& Santos, C. P. Dos. 1999. Limnoperna fortunei (Dunker 1857), molusco bivalve invasor na bacia do Guaíba, Rio Grande do Sul, Brasil. Biociências 7(2):147-149.

Mansur, M. C. D.; Santos, C. P.; Darrigran, G.; Heydrich, I.; Callil, C. T. \& Cardoso, R. C. 2003. Primeiros dados qualiquantitativos do mexilhão-dourado, Limnoperna fortunei (Dunker), no Delta do Jacuí, no Lago Guaíba e na Laguna dos Patos, Rio Grande do Sul, Brasil e alguns aspectos de sua invasão no novo ambiente. Revista Brasileira de Zoologia 20(1):75-84.

Montalto, L. \& Drago, I. E. 2003. Tolerance to desiccation of an invasive mussel, Limnoperna fortunei (Dunker, 1857) (Bivalvia, Mytilidae), under experimental conditions. Hydrobiologia 498:161-167.

Morton, B. 1977. The populations dynamics of Limnoperna fortunei (Dunker, 1857) (Bivalvia Mytilidae) in Plover Cove reservoir, Hong Kong. Malacologia 16:165-182.

1996. The aquatic nuisance species: a global perspective and review. In: D' ITRI, F. ed. Zebra Mussels and other aquatic species. Ann Arbor, Michigan. 1-54p.

Niencheski, L. F. \& Baumgarten, M. G. 1997. Environmental Chemistry. In: Seeliger, U.; Odebrecht, C. \& Castello, J. eds. Subtropical Convergence Environments: the coast and sea in the southwestern Atlantic. Berlin, Springer-Verlag. 20-23p.

RICCIARDI, A. 1998. Global range expansion of the asian mussel Limnoperna fortunei (Mytilidae): another fouling threat to freshwater systems. Biofouling 13(2):97-106.

Recebido em agosto de 2006. Aceito em julho de 2007. ISSN 0073-4721

Artigo disponível em: www.scielo.br/isz 